\title{
EFFECT OF CALORIE RESTRICTION AND EXERCISE ON TYPE 2 DIABETES
}

\author{
Hira Shakoor ${ }^{1}$, Vasso Apostolopoulos ${ }^{2}$, Jack Feehan ${ }^{2,3}$, Habiba Isse Ali ${ }^{1}$, \\ Leila Cheikh Ismail $^{4,5}$, Ayesha Salem Obaid S. Al Dhaheri ${ }^{1}$, Lily Stojanovska ${ }^{1,2}$ \\ ${ }^{1}$ Department of Nutrition and Health, College of Medicine and Health Sciences, United Arab Emirates, Al Ain, United Arab Emirates \\ ${ }^{2}$ Institute for Health and Sport,Victoria University, Melbourne, Australia \\ ${ }^{3}$ Department of Medicine-Western Health, Melbourne Medical School, The University of Melbourne, St. Albans, Australia \\ ${ }^{4}$ Department of Clinical Nutrition and Dietetics, College of Health Sciences, University of Sharjah, Sharjah, UAE \\ ${ }^{5}$ Nuffield Department of Women's \& Reproductive Health, University of Oxford, Oxford, UK
}

Corresponding author: Lily Stojanovska, Department of Nutrition and Health, College of Medicine and Health Sciences, United Arab Emirates University, PO Box 15551, Al Ain, United Arab Emirates. Email:lily.stojanovaska@, uaeu.ac.ae Phone: +971525308064

\begin{abstract}
Type-2 diabetes (T2D) is a chronic condition, generally regarded as an irreversible, that is among the top 10 causes of death globally. The hallmark of T2D is hyperglycemia, which results from disturbances in insulin sensitivity, insulin secretion, $\beta$-cell dysfunction and insulin resistance. Several clinical and lifestyle factors are involved in the progression of $\mathrm{T} 2 \mathrm{D}$, such as obesity and physical inactivity. A high-calorie diet is the main contributor to the development of obesity, which results in T2D, as obesity or increased intra-abdominal adipose tissue is related to insulin resistance. Technological advances have contributed to individuals having a more sedentary lifestyle, leading to obesity and T2D. T2D can be treated with lifestyle interventions, such as diet and exercise. Herein, we highlight the positive impact of a very low-calorie diet (VLCD) and lifestyle modalities in the treatment and prevention of T2D. An inclusion of VLCD 400-800 $\mathrm{kcal} /$ day for 8 weeks and $\geq 150$ minutes exercise 5 times a week as lifestyle interventions can decrease glucose levels to normal, reduce $\mathrm{HbAlc}$ and improve insulin resistance and sensitivity. Therefore, a potential mechanism in maintaining glucose homeostasis and remission of T2D by VLCD and exercise reduces body weight.
\end{abstract}

Keywords: Hyperglycemia, very low-calorie diet, insulin sensitivity, insulin resistance, type 2 diabetes

\section{INTRODUCTION}

Type-2 Diabetes (T2D) is a complex metabolic disorder characterized by hyperglycemia due to an impairment in macronutrient metabolism. T2D is associated with a high risk of micro- and macrovascular co-morbid disease [1]. The first known reference to T2D comes in Egyptian manuscripts from 3000 years ago [2], and in the modern era is amongst the top 10 causes of death worldwide. Globally, 425 million people are affected by
T2D, which is forecasted to increase to 693 million by 2045 [3]. This increasing trend in diabetes incidence is a significant economical burden, and currently, about US $\$ 727$ billion are being spent annually on those suffering from T2D equating to one in every eight dollars spent on healthcare [3]. T2D was first considered as one of the central components of metabolic syndrome. However, it is now recognized as a complex endocrine and metabolic 
disorder that results in hyperglycemia secondary to advancing insulin resistance [4]

Calorie restriction and exercise are known to promote healthy aging and decrease hyperglycemia; hence, it is central to the management of T2D [5]. Studies show that very low-calorie diets (VLCD) for short durations are effective in managing T2D [6,7]. VLCDs cause significant weight loss with reductions of $5-10 \%$ body weight improving blood glucose, lipid profile and blood pressure [8]. However, adhering to chronic and extreme diets like VLCD is challenging for this population, and has some negative consequences on health [5]. This review focuses on the therapeutic potential and challenges of VLCD and exercise for the management of T2D.

\section{METHODOLOGY}

A literature search was conducted using a Science Direct, PubMed, Web of Science, SCOPUS, Springer and Google Scholar databases. Search terms included "Diabetes" OR "Type 2 Diabetes" OR "Hyperglycemia" OR "Hyperinsulinemia" OR "Insulin Resistance" AND "Pathogenesis" OR "Inflammation" OR "Cytokines" OR " $\beta$-cells dysfunction" AND "Dietary Intervention" OR "Calorie Restriction" OR "Low-Calorie Diet" OR "Very Low-Calorie Diet" OR "Fasting" AND "Lifestyle Intervention" OR "Physical Activity" OR "Exercise" OR "Aerobic" OR "En- durance Training" OR "Resistance Training” OR "Combined Training." Although many articles are available that discuss the effects of dietary restriction and exercise individually on diabetes, the current review primarily focused on the combined effect of the two on T2D outcomes. Studies that focus on human studies were identified and those articles containing relevant data were thoroughly reviewed (Fig. 1). The reviewing process considered the modification of lifestyle (calorie restriction and exercise) and how this modality reduces the burden of T2D.

\section{PATHOGENESIS OF TYPE 2 DIABETES}

Diabetes is condition characterized by disruption in the balance between plasma glucose levels and glucose uptake by the tissues, with resultant hyperglycemia. High plasma glucose concentrations stimulate insulin secretion from the $\beta$-cells of the pancreas, which in turn stimulates glucose uptake by the peripheral tissues, most notably the liver, muscle and fat tissue. Insulin also acts to suppress muscle glycogenolysis, adipose lipolysis and hepatic gluconeogenesis to maintain glucose homeostasis [9]. In diabetic patients, chronic hyperglycemia, with resultant hyperinsulinemia leads to progressive insulin resistance, impairing glucose uptake. A positive cycle of insulin resistance and hyperglycemia leads to persistent hyperinsulinemia. Over time, the pancreatic

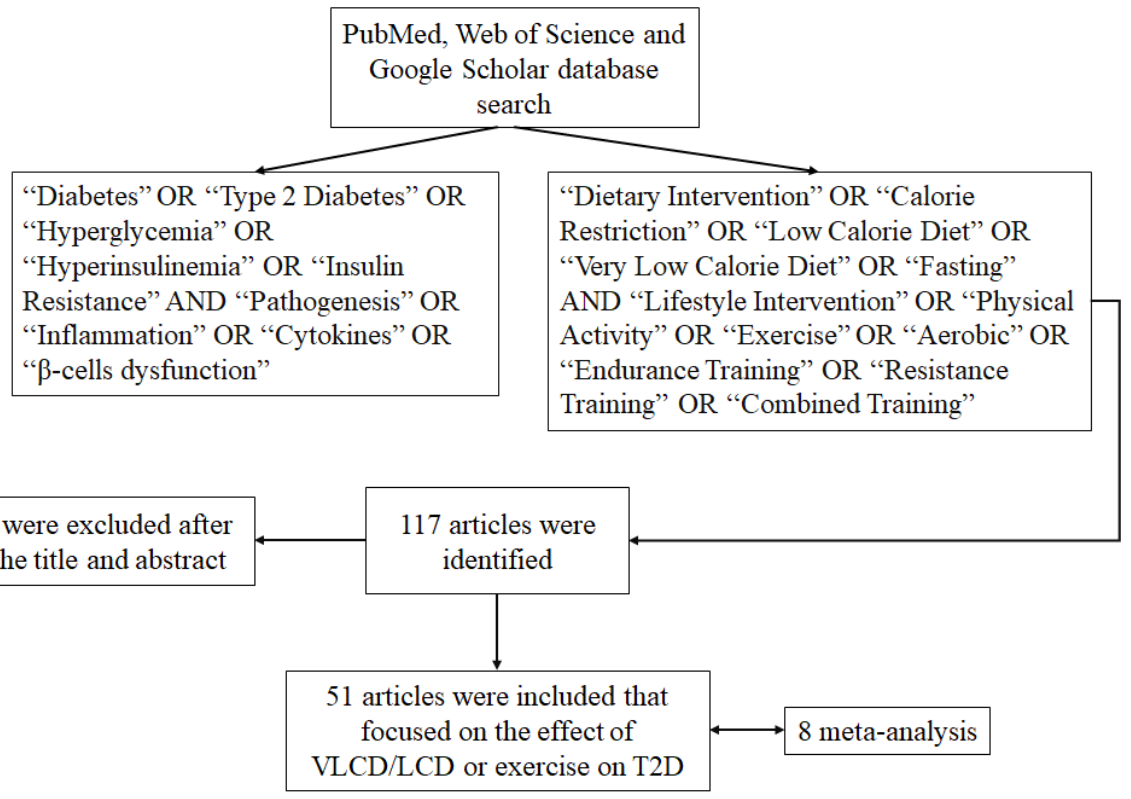

Fig. 1. Search Methodology 
$\beta$-cells cannot maintain insulin production, leading to dysfunction [10]. Additionally, insulin is a powerful inhibitor of lipolysis; even mild elevations of insulin in the plasma cause a remarkable reduction in free fatty acid levels [11].

When glucose homeostasis is disrupted, the risk of T2D increases. The pathophysiology of T2D centres on two main factors: progressive peripheral resistance to insulin and pancreatic $\beta$-cell dysfunction with their eventual failure.

\section{Insulin resistance}

Chronic hyperglycemia due to factors such as poor diet and obesity leads to ongoing insulin release, and eventually the tissues lose responsivity to the hormone. Resistance to insulin action leads to the impairment of insulin-mediated glucose uptake in peripheral tissues (particularly the muscle and fat); impairment of triglyceride uptake by the adipose tissue and incomplete suppression of hepatic glucose output. To maintain glucose homeostasis in these conditions, $\beta$-cells secrete more insulin, leading to hyperinsulinemia [16]. Chronic hyperinsulinemia causes a reduction in the sensitivity of insulin, known as resistance. The main outcome of insulin resistance is to reduce glucose uptake and utilization by most body cells, with the exception of neuronal and endothelial cells. Consequently, this decrease in the uptake and utilization of glucose results in hyperglycemia 21 . Additionally, obesity and intra-abdominal adipose tissue are also related to insulin resistance, with evidence suggesting that in T2D it increases in parallel with adiposity [19]. Adipose tissue is sequestered in different locations throughout the body, with varied physiological impacts, with the primary two forms being subcutaneous fat under the skin, and visceral fat surrounding the abdominal organs. Subcutaneous fat is considered to be less active, with lower adipokine secretion and less macrophage infiltration [20]. Visceral adipose tissue is a highly active secretory organ, releasing adipokines (such as adiponectin, leptin, interleukin [IL-6] and tumor necrosis factor- $\alpha$ ) directly into the portal circulation affecting hepatic glucose and lipid metabolism. High levels of adipokines induce a pro-inflammatory and oxidative state, further reducing insulin sensitivity and exacerbating insulin resistance [21]. Together, insulin resistance and $\beta$-cell dysfunction eventually lead to T2D (Fig. 2).

\section{Pancreatic $\beta$-cells}

In T2D, the early stages of $\beta$-cell dysfunction are characterized by impairment of the secretion of insulin and ultimately leads to the onset of glucose intolerance [13]. In the first phase of the

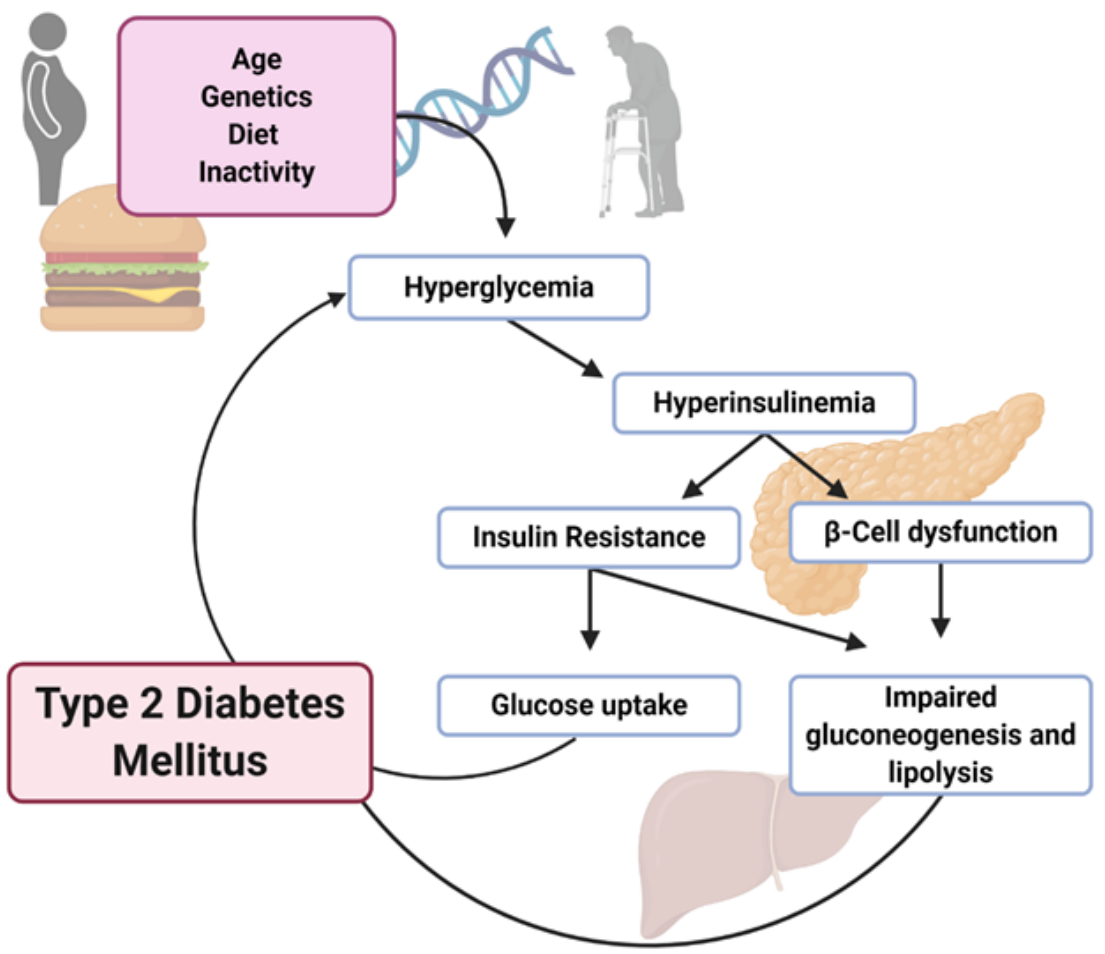

Fig. 2. Pathophysiology of type-2 diabetes 
progression of diabetes, insulin secretion is elevated to maintain glucose homeostasis in the face of insulin resistance and the resulting hyperglycemia [14]. However, in the second phase, when the disease progresses, there is an impairment of newly synthesized insulin. This condition is reversible in some patients by ongoing glycemic control. On the other hand, if hyperglycemia persists, it will lead to the inhibition of glucose mediated insulin release. Moreover, it can cause accumulation of glycogen in the $\beta$-cells due to sustained hyperglycemia, leading to a phenomenon known as $\beta$-cell glucotoxicity or desensitization [15].

\section{The complications of type-2 diabetes}

People living with T2D are at elevated risk of both micro- and macrovascular diseases. Common macrovascular outcomes include peripheral vascular disease, coronary heart disease and stroke, and common microvascular complications include polyneuropathy, retinopathy and nephropathy. There are also a number of diabetic outcomes related to both micro- and macrovascular damage such as diabetic foot (Fig. 3). The risk of mortality and morbidity is more closely related to macrovascular degeneration compared to microvascular complications in older people. Generally, complications of T2D are divided into two categories:

1. Acute metabolic complications, which are generally short term, such as ketoacidosis, hypoglycemia and hyperglycemia.

2. Late systemic complications, which are long term chronic complications including polyneuropathy and cardiovascular disease. [22]

Microvascular complications are strongly related to hemoglobin $\mathrm{A} 1 \mathrm{c}(\mathrm{HbA} 1 \mathrm{c})$, whereas macrovascular complications may develop earlier but do not correlate closely with HbAlc. Glucotoxicity and lipotoxicity secondary to hyperglycemia, hyperinsulinemia and $\beta$-cell dysfunction, underlie the complications of T2D, and these early pathophysiologic events are at least partially reversible. However, the management of hyperglycemia in the later stages of T2D is unlikely to reverse macrovascular damage and resulting cardiovascular disease. This highlights the impact of early intervention to improve hyperglycemia and prevent/delay long-term microvascular and macrovascular complications [23].

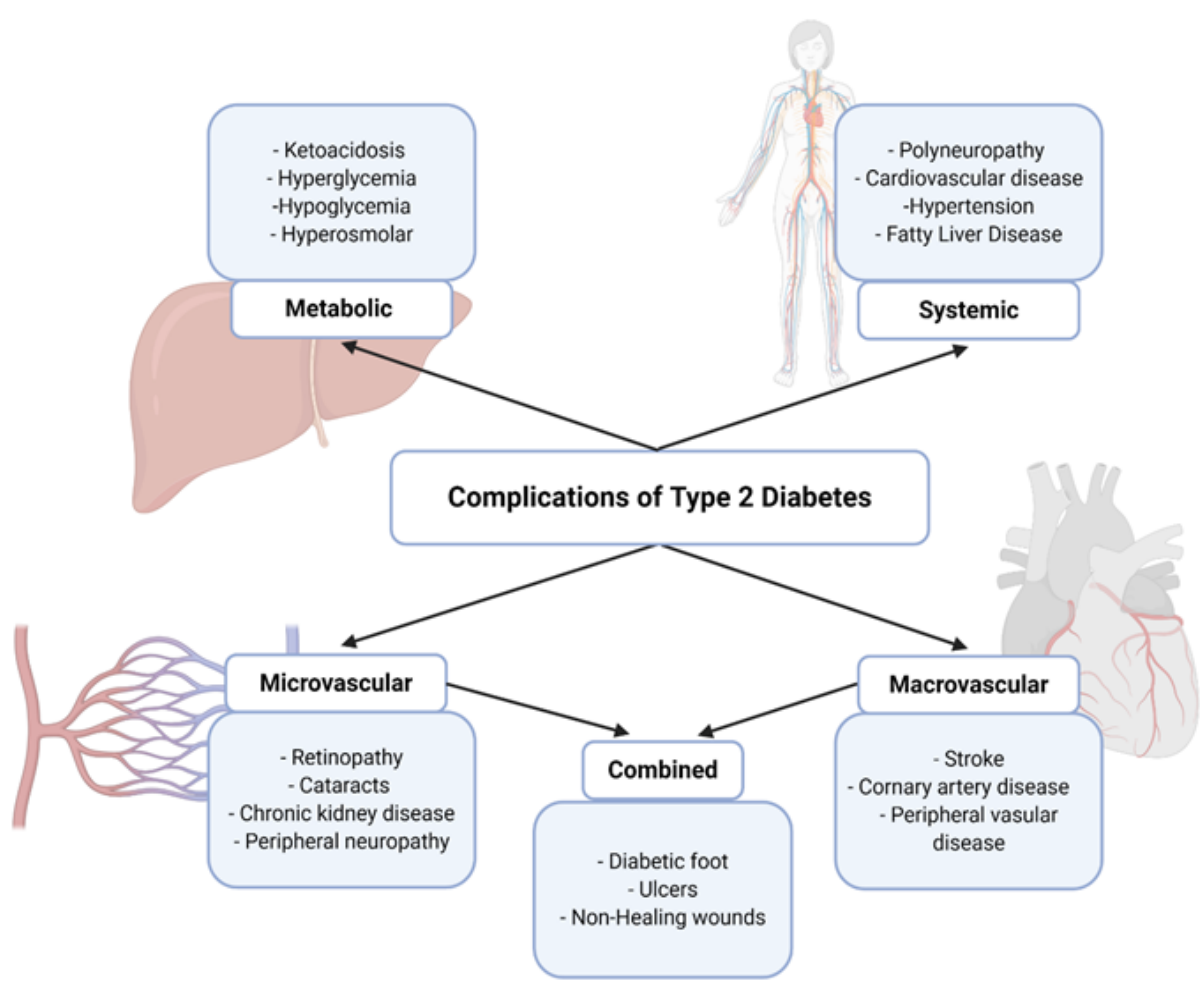

Fig. 3. Complications of type-2 diabetes 
INFLAMMATION AS A RISK FACTOR FOR TYPE 2 DIABETES

The innate immune system is the first line of defense against chemical, or physical injury, and microbial invasion, which works to restore homeostasis by eliminating threats and repairing tissue damage. The systemic component of the innate immune response is known as the acute phase response which relies upon a diverse range of inflammatory mediators known as cytokines. Cytokines are small proteins that are involved in cell signaling pathways for interaction and communication. Cytokines stimulate the production of acute-phase proteins from the liver, such as C-reactive protein (CRP), serum amyloid A, alpha-1-acid glycoprotein, complement and fibrinogen. The level of these acute-phase proteins, may increase or decrease during injury and inflammation. Interestingly, these inflammatory markers are also known to increase in metabolic syndrome as well as in T2D [24]. In T2D, high CRP levels are related to advanced stages of atherosclerosis, particularly in patients with elevated $\mathrm{HbAlc}$ levels and a high concentration of advanced glycation end products [25]. Additionally, in a range of chronic conditions including T2D, tumor necrosis factor (TNF)- $\alpha$ levels are known to increase. There are several factors including nutrition, physical inactivity and age which contribute to the activation of the innate immune system underlying the increased secretion of cytokines and associated inflammation. However in those living with diabetes, the chronic inflammation has important consequences. Inflammatory proteins, CRP, interleukin-6 (IL-6) and TNF- $\alpha$ are all known to exacerbate insulin resistance, T2D and metabolic syndrome. Additionally, high IL- 6 and TNF- $\alpha$ are also associated with obesity, T2D, heart disease and endothelial dysfunction [25]. Individuals with impaired glucose tolerance or impaired fasting glucose show higher levels of IL-6 compared to healthy individuals [26], and others have noted that inflammatory markers are related to insulin resistance, but not to insulin secretion [27]. Inhibiting IL-6 signaling through administration of anti-IL-6 receptor monoclonal antibodies results in improved insulin sensitivity and decreased $\mathrm{HbA} 1 \mathrm{c}$ levels providing evidence for a therapeutic benefit in countering chronic inflammation in T2D [28]. However, it has also been shown that a combination of calorie restriction to $500 \mathrm{kcal} /$ day, sibutramine (appetite suppressant drug) and an exercise program for 12 weeks in obese individuals leads to meaningful decrease in IL-6 levels [29]. Calorie restriction and regular exercise also improve insulin action, insulin sensitivity and fasting blood glucose levels by reducing body fat, macrophage accumulation and inflammatory cytokine concentrations, with broad anti-inflammatory effects [30] as illustrated in (Fig.4).

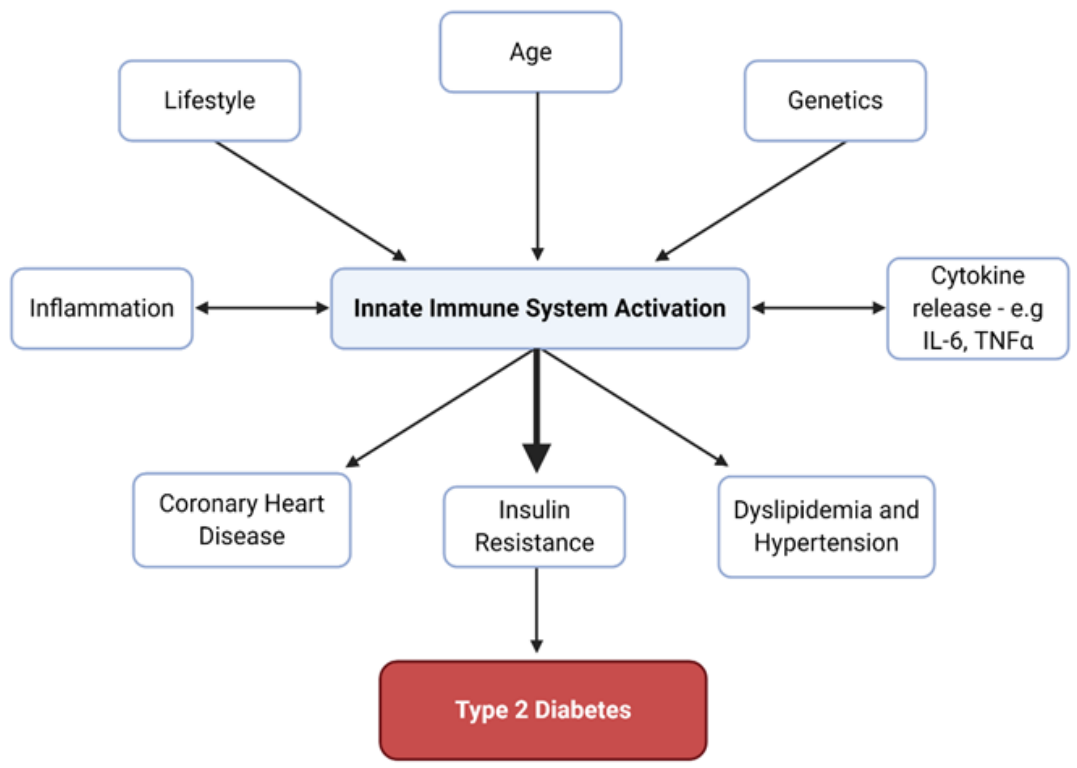

Fig. 4. Activation of innate immune system and progression of diabetes 
OBESITY AS A RISK FACTOR FOR TYPE 2 DIABETES

Obesity results from a chronic imbalance between energy intake and expenditure, with multifactorial contributions from genetic, epigenetic, physiological, behavioral, socio-cultural and environmental factors [31]. Obesity is related to a wide range of adverse effects on health, including increased risk of disease, disability and death. Obesity has been recognized as a medical disorder since the height of ancient Greece, and the Hindu physician Sushrut (500-400BC) identified that obesity is linked with other diseases including T2D [32]. Obesity is involved in an increased risk of various diseases, including metabolic syndrome, nonalcoholic fatty liver, autoimmune disorders, gout, osteoarthritis, obstructive sleep apnea and cancer [33].

Obesity causes alterations to both the metabolic and endocrine functions of adipose tissue [34]. Increased macrophage accumulation in adipose tissue causes metabolic complications of obesity including insulin resistance and T2D [35]. Obesity leads to high levels of fatty acids and hormones, low lipid turn-over and an increase in inflammatory macrophages that cause activation of pro-inflammatory cytokines (TNF- $\alpha$, IL-6) [36]. This pro-inflammatory milieu contributes to insulin resistance, T2D, cardiovascular disease, and other co-morbid disorders [34], therefore, obesity is a known risk factor that causes the development of T2D.

Obesity is thought to contribute to approximately $70 \%$ of diabetes cases [37]. In the last decade, dietary patterns have shifted towards unhealthy food (junk and fast foods) worldwide [38]. However, this is contrary to modern nutritional science, which emphasizes a varied diet rich in fresh food. It is known that poor diet has a widespread impact on cardiometabolic risk factors that not only include obesity and dyslipidemia but also blood pressure, glucose-insulin homeostasis, lipoprotein concentrations and function, oxidative stress, inflammation, endothelial health, hepatic function, adipocyte metabolism, cardiac function, metabolic expenditure, pathways of weight regulation, visceral adiposity, and the microbiome [39]. Therefore, a healthy diet and active lifestyle is suggested to decrease the risk of life-threatening disease. For greater health benefits, general dietary guidelines main- ly focus on reducing the intake of dietary fats, particularly saturated and trans, cholesterol, refined grains, sodium, and added sugar [39]. Physical activity and a balanced diet decrease intra-abdominal fat, and reduce the impact of its metabolic effects [40] thereby improving insulin sensitivity and reducing the progression of T2D. Studies have shown that a hypocaloric diet reduces body mass, BMI, body fat percentage, waist to hip ratio, and leptin production [41]. A study of 60 obese women who ate a very low-calorie diet that included four phases (Intensive: 450$680 \mathrm{kcal}$, transition: $800-880 \mathrm{kcal}$, maintenance: 1000-1400 kcal, stabilization: $1200 \mathrm{kcal})$. This was delivered alongside an exercise intervention of 60 minutes of moderate exercise, 20-30 minutes of aerobic training, followed by $20-30$ minutes of resistance exercise. They found an improvement in body composition, quality of life and cardiovascular risk factors [42]. Another cohort of 191 obese, nondiabetic patients were provided with $800-1000 \mathrm{kcal} /$ day for 8 weeks. Transcriptome profiling of participant showed improvements in genes related to weight, lipid profile and glucose level [43].

\section{MANAGING TYPE 2 DIABETES}

\section{Calorie restriction and weight reduction}

Dietary interventions that provide adequate nutrition but are low in energy are known as calorie restriction (CR). As there are a number of intrinsic links to calorie intake, glucose homeostasis and obesity, calorie restriction aids in the prevention and management of T2D. Evidence has shown that calorie restriction in obese individuals increases insulin sensitivity and decreases acute insulin response to glucose [44]. In fact, calorie restriction improves insulin sensitivity by as much as $40 \%$, as well as assisting in improved $\beta$-cell responsiveness of to glucose [45]. Very low calorie diet (VLCD) treatment for weight reduction consist of four phases: (1) initial phase: patients consume a balanced LCD of 1200 to $1500 \mathrm{kcal}$ daily for 1 to 4 weeks; (2) modified fast phase: consumption of VLCD only; (3) refeeding phase: reintroducing solid food; and (4) stabilization/ maintenance phase: which focuses on nutritional education and behavior modification that help to sustain weight loss [1]. VLCD treatment can results in achiev- 
ing an average weight loss of 1 to $2 \mathrm{~kg} /$ week for women and 1.5 to $2.5 \mathrm{~kg} /$ week for men [2,3]. It was observed that rapid weight reduction could increase the risk of gallstones that results in cholecystectomy [4]. Therefore, it is advised that the rate of weight loss should not exceed an average of $1.5 \mathrm{~kg} /$ week [5] to minimize the adverse effect of VLCD. Likewise, a study included seven obese patients with non-insulin-dependent diabetes mellitus (NIDDM) underwent four periods of low-calorie intake: (i) baseline weight maintenance diet for seven days, (ii) followed immediately by a calorie restriction diet (800 kcal/day) for seven days, (iii) followed by weight loss program for two months comprising of a very low-calorie diet $(400 \mathrm{kcal} /$ day) then four weeks of gradual refeeding and weight maintenance diet for seven days, (iv) a final week of calorie restriction of $800 \mathrm{kcal} /$ day. This calorie restriction was associated with significant reductions in weight and BMI of the obese individuals, which decreased from 32.8 \pm 2 to $27.5 \pm 1.3 \mathrm{~kg} / \mathrm{m} 2$. Even the short duration of calorie restriction ( $800 \mathrm{kcal} /$ day) caused substantial reductions in fasting plasma glucose, hepatic glucose production, fasting plasma triglycerides, and increased insulin sensitivity and secretion. Additionally, the four different calorie intake periods demonstrated that restriction had an important regulatory effect on the metabolism of obese patients with NIDDM which was independent of weight loss [46].

Interestingly, a systematic review and meta-analysis identified six randomized control trials where VLCDs showed greater weight reduction in the short term but similar weight loss in the long term compared to LCD diets [47]. This is likely due to challenges in compliance on both diets, but particularly VLCDs. VLCDs has been used over the past 40 years, and the management of obesity and weight loss has been recognized in various nutritional guidelines. A longitudinal qualitative study of 18 participants showed that very low energy diets of $<800 \mathrm{kcal} /$ day for 8 weeks, reduced weight and led to diabetes remission [48]. An early study also showed that insulin-treated T2D patients with on the VLCD diet approach had significant weight reduction, which leads to the cessation of insulin treatment in some patients [49]. However, have VLCD shown some side effects such as dizziness, constipation, diarrhea, flatulence, sensitivity to cold, fatigue, dry skin, halitosis, gallstones and hair loss, with LCD better tolerated [50].
Effects of physical activity in the management of diabetes

Physical inactivity is a significant risk factor for T2D, thought to play a role in as many as $90 \%$ of cases [51]. According to World Health Organization reports and recommendations, exercise improves both physical and mental well-being and regular moderate-intensity exercise reduces cardiovascular disease, T2D and cancer [52] making exercise imperative in the management and prevention of diabetes. Physical activity as also a cost-effective therapeutic approach with few known side effects, significantly improving life quality, immune function and reducing the risk of various life-threatening diseases [53]. Most of the clinical studies that have evaluated exercise interventions in T2D have used an exercise frequency of three times per week, [54,55] however current physical activity guidelines recommend five sessions of moderate activity weekly [56,57]. Aerobic exercise for 45 minutes, three times per week over eight weeks at $50-70 \%$ heart rate, demonstrated a reduction in insulin resistance [58]. However, the effect of a single bout of exercise on insulin sensitivity lasts for 24-72 hours, depending upon the duration and intensity of the activity [59]. Generally, the duration of insulin sensitivity is not more than 72 hours, and so this should guide prescription or use, with no more than 72 hours elapsing between successive exercise sessions [60]. Four international diabetes associations, Diabetes UK, the Canadian Diabetes Association, the American Diabetes Association, and the European Association for the Study of Diabetes have reported training recommendations for T2D and are summarized in Table 1 . These associations recommend a moderate to moderate intensive activity for T2D patients.

\section{Different types of training.}

a) Moderate intensity is generally classified as $55-69 \%$ of maximum heart rate (HRmax) and $55-69 \%$ of maximum oxygen consumption (VO2 max); vigorous training exercise is defined as $70-85 \%$ HRmax, (70-85\% of VO2 max); and intensive exercise is defined as having greater than $85 \%$ of HRmax, ( $>89 \%$ of VO2 max) [61]. In one systematic review, 47 randomized trials with over 8500 participants were selected to determine the effect of physical activity on glycemic control. It was noted that the exercise of 
Table 1. Exercise recommendations for type 2 diabetes by international associations

\begin{tabular}{ccccc}
\hline Associations & $\begin{array}{c}\text { Training } \\
\text { type }\end{array}$ & $\begin{array}{c}\text { Frequency } \\
\text { (per week) }\end{array}$ & $\begin{array}{c}\text { Duration (min/ } \\
\text { week) }\end{array}$ & Intensity \\
$\begin{array}{c}\text { American Diabetes } \\
\text { Association (ADA) }\end{array}$ & ET, RT, CT & $\geq 5$ & $\geq 150$ & Moderate intensity \\
$\begin{array}{c}\text { Canadian Diabetes } \\
\text { Association (CDA) }\end{array}$ & ET, RT, CT & $\geq 5$ & $\geq 150$ & $\begin{array}{c}\text { Moderate to } \\
\text { moderate intensive }\end{array}$ \\
$\begin{array}{c}\text { European Association } \\
\text { for the Study of } \\
\text { Diabetes (EASD) }\end{array}$ & ET, RT, CT & - & $\geq 150$ & $\begin{array}{c}\text { Moderate to } \\
\text { moderate intensive }\end{array}$ \\
Diabetes UK & ET & $3-5$ & $\begin{array}{c}15-60 \mathrm{~min} / \\
\text { session }\end{array}$ & Moderate \\
\hline
\end{tabular}

Endurance training (ET), Resistance training (RT), Combined training (CT)

more than $150 \mathrm{~min} /$ week was effective for cardiovascular health and improved T2D outcomes [62]. Therefore, it is recommended to have 150 $\mathrm{min} /$ week of moderate activity or $75 \mathrm{~min} /$ week of vigorous activity.

b) Strength training is an effective form of exercise for building bones, muscle strength, burning fat and increasing general metabolism. Evidence shows that physical activity during menopause prevents weight gain and reduces the risk of heart disease, T2D and cancer $[63,64]$. Aerobic exercise has been reported to result in a greater reduction in $\mathrm{HbA} 1 \mathrm{c}$ when compared to resistance training. However, combined resistance and aerobic exercise training was significantly better than only aerobic exercise. Similarly, some long term endurance training intervention studies showed a significant reduction in $\mathrm{HbA1c}$, which indicates that endurance training is associated with reducing T2D risk $[65,66]$.

In a systematic review and meta-analysis, it was shown that 3,600 Metabolic Equivalent (MET) minutes/week reduced the risk of T2D by $19 \%$ [67]. Another study of 98 participants, receiving lifestyle intervention of 5-6 aerobic and combined aerobic and strength training sessions for 30-60 minutes a week for 12 months found remission of diabetes in $23 \%$ of participants [68]. Similarly, 98 participants with T2D who performed 5 to 6 aerobic training sessions of 30-60 minutes per week alongside 2 to 3 of resistance training showed reductions in $\mathrm{HbAlc}$, glycemic control and need for glucose-lowering medications [69].
Combination of very-low-calorie diet and exercise in improving the biomarkers of type-2 diabetes

Insulin resistance is related to the etiology of T2D in both aging and obesity. However, the exact causes for the development of insulin resistance are still unclear but it is thought that overnutrition, overweight and obesity are the major contributing factors [70]. Sedentary lifestyle, and alterations in glucose metabolism due to aging and mitochondrial function are also believed to cause insulin resistance [71]. Combination of both calorie restriction and exercise have been shown to significantly decrease insulin levels in the plasma and improve insulin sensitivity in middle-aged obese and elderly overweight individuals [72]. The insulin-dependent glucose transporters are associated with specific classes of skeletal muscle oxidative metabolism. Skeletal muscle is of two types: low oxidative skeletal muscle (type 1 slow-twitch), the main fuel source are triglycerides, fatigue slowly and use aerobic respiration; fast oxidative skeletal muscle (type 2 fast-twitch), in which the main fuel source is glycogen, break down ATP quickly, contraction force is greater and while also using aerobic respiration. Low oxidative type skeletal muscle tissue has less glucose transporters 4 (GLUT4); and hence, shows a decrease in insulin sensitivity compared to high oxidative fibers [73]. Exercise helps increase both mitochondrial and GLUT4 content in skeletal muscle, improving glucose transport and utilisation in the muscle. 
Evidence shows that exercise increases mitochondrial content and electron transport chain activity, whereas calorie restriction improves insulin sensitivity in overweight older adults [74]. Weight reduction secondary to calorie restriction also improves tyrosine kinase activity, the enzyme responsible for the transfer of a phosphate group from the ATP molecule to a protein in skeletal muscle insulin receptors [75], thus increasing the concentration and function of GLUT4 receptors, however it is unable to activate muscle glycogen synthase by insulin. Different mechanisms, such as the depletion of muscle glycogen, are involved in improving insulin sensitivity with calorie restriction, however the undelying mechanisms require further investigation [46]. Thus, taken together the evidence suggests that the combination of VLCD and physical activity results in weight loss and a decrease in T2D risk. A systematic review of studies showed that aerobic activity and diet combination resulted in greater reductions in weight and fasting glucose level [76]. Likewise, the long-term effect of exercise and VLCD for 16 weeks in twenty-seven obese, insulin-dependent T2D participants was observed. Patients followed a combination of VLCD, consisting of $450 \mathrm{kcal} /$ day, with a weekly exercise program of $30 \mathrm{~min}$ aerobic exercise for four months at $70 \%$ of maximum heart rate. Bodyweight and the glucoregulatory parameters significantly improved after the four-month intervention period compared to the baseline value. Body weight $(\mathrm{kg})$ in this group decreased from 114 \pm 5 to $86 \pm 4$ and HbAlc (\%) from $7.8 \pm 0.4$ to $6.3 \pm 0.4$ [77]. Studies that report a reduction in the risk of T2D through the combination of a low calorie diet and physical activity have been summarized in Table 2.

T2D and excess adiposity are linked with one another. Recent evidence shows that weight reduction through medical interventions or bariatric surgery can cause remission in T2D in young people and in those with recent onset of disease [78]. The Diabetes Intervention Accentuating Diet and Enhancing Metabolism (DIADEM-I) study is a current, non-blinded, pragmatic, randomized, controlled, parallel-group trial. It includes 138 subjects, younger adults with T2D, in the early stage of diabetes $(\leq 3$ year duration) who have undergone intensive lifestyle intervention changes (i.e., $800 \mathrm{kcal} /$ day intake and $150 \mathrm{~min} /$ week exercise for 12 weeks) and results are hoped to identify a path to reversal of
T2D [78]. Recent evidence has also reported that low-calorie diet and lifestyle interventions resulted in a significant improvement and T2D remission [79]. For, instance, An open-label cluster-randomized primary care trial, (the DiRECT study), of 49 primary care practices in Scotland and the Tyneside region of England, demonstrated the impact of a low energy diet (LED) for T2D remission. This study followed the participants for 12 months, and it was shown that $24 \%$ of the LED intervention group achieved 15 $\mathrm{kg}$ weight loss, with nearly half $(56 \%)$ achieving full remission [79]. Similarly, evidence showed that calorie restriction combined with exercise improved blood pressure, glucose level, lipid profile, inflammatory cytokines, reduce insulin resistance, HbAlc, circulating level of leptin, weight and waist circumference [80,81].

\section{VLCD treatment Safety and Precautions}

VLCD therapy is safe for BMI $>30 \mathrm{~kg} /$ $\mathrm{m}^{2}$ along with regular medical supervision but for overweight individuals with BMI of 27-30 $\mathrm{kg} / \mathrm{m} 2$, VLCD should only reserved to those who have any weight-related medical problems $[94,96]$. BMI $\geq 30 \mathrm{~kg} / \mathrm{m} 2$ is a risk factor for cardiovascular morbidity and mortality, therefore substantial weight reduction is necessary to improve quality of life [100]. Generally, National Institute of Health $(\mathrm{NIH})$ recommends to reduce energy intake by $500 \mathrm{kcal} /$ day to those who have class I obesity [101]. Individuals with class II and class III obesity should restrict to $500-1000 \mathrm{kcal} /$ day reduction. By reducing $500 \mathrm{kcal} /$ day energy intake, a person can achieve $0.5 \mathrm{~kg} /$ week weight loss [102].

However, VLCD treatment is not advisable for childern and adolescents. VLCD can effect normal body growth, protein intake and increase nitrogen loss $[103,104]$. Also VLCD terapy is not considered safe for adults older than 50 years. Older people are at higher risk of negative nitrogen balance with weight loss as they have already depleted lean body mass and low immune response [105]. Similarly, VLCD is not appropriate for pregnant and lactating women as they have increased nutritional requirements [106]. Furthermore, other people that should be excluded from VLCD treatment are those suffering from cardiac disease, hepatic disease, renal disease, infectious disease, psychiatric disease (bulimia nervosa or anorex- 
Table 2. Studies showing the effect of very low calorie diet, low calorie diet and exercise on type-2 diabetes

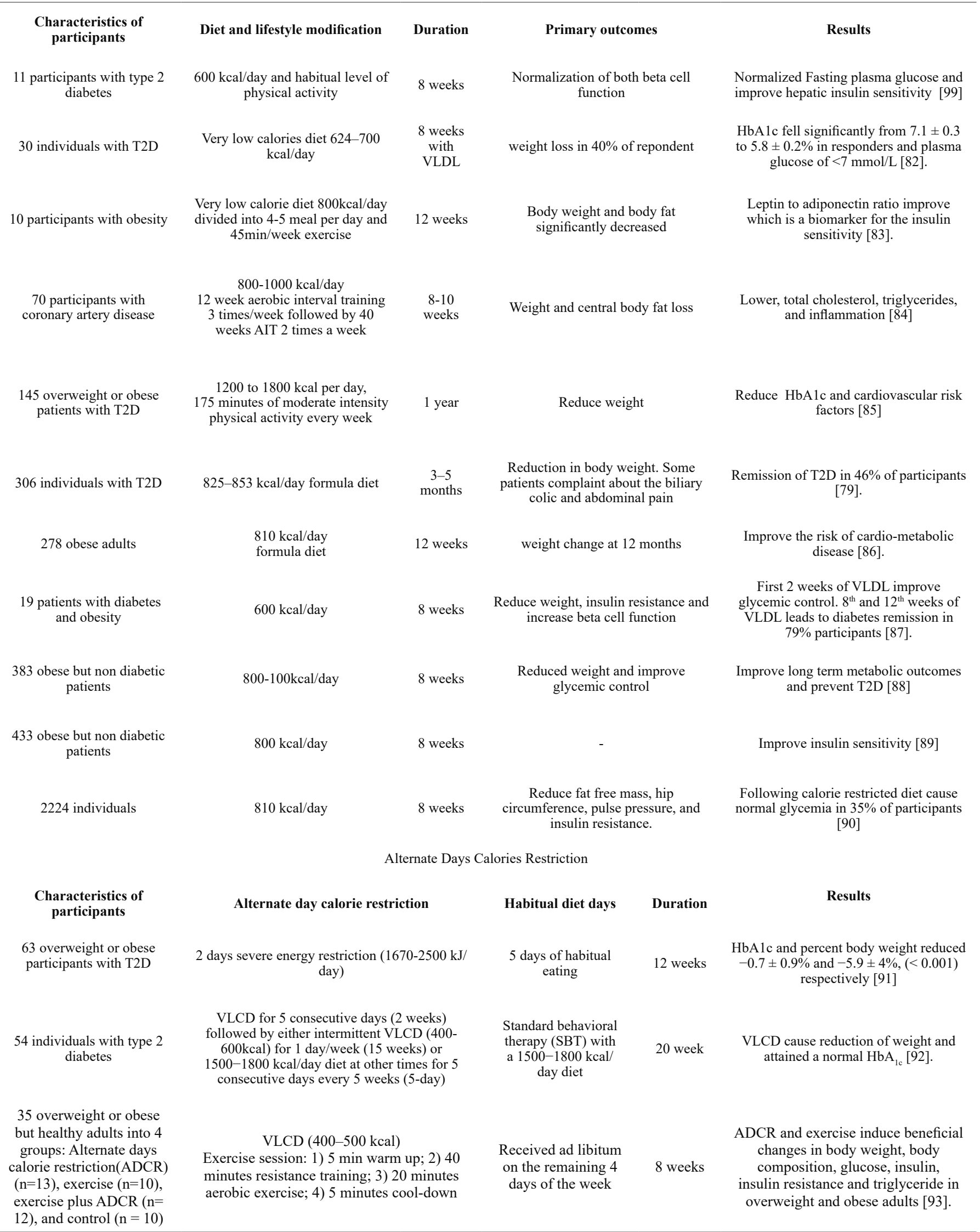

$\mathbf{V L C D}=$ Very Low Calorie Diet, $\mathbf{L C D}=$ Low Calorie Diet, $\mathbf{A D C R}=$ Alternate Day Calorie Restriction 
ia nervosa) and type 1 diabetes because of severe ketosis or hypoglycemia [94].

The VLCD is known to reduce weight while preserve lean body mass, achieved by providing greater amount of dietary protein 0.8 to $1.5 \mathrm{~g}$ protein $/ \mathrm{kg}$ ideal body weight [107]. Protein can be provided in form of milk, soy, or egg-based powder (mixed with water). Vitamins and mineral supplements should be given to fulfill body needs $[96,108]$. To maintain electrolyte balance, 3 to $5 \mathrm{~g}$ of sodium chloride, and $3 \mathrm{~g}$ of potassium will be given and patients should be asked to drink 1.5 to $2 \mathrm{~L}$ of noncaloric fluid per day[109]. Maintaining proper hydration is very important during VLCD treatment to prevent orthostatic hypotension [110].

Patients receiving VLCD should be monitored during first 2 weeks of rapid weight loss as the side effects from VLCD therapy are common during the first 2 weeks of treatment [111]. It is difficult to maintain weight loss in a long term after VLCD treatment. Maintenance of weight loss can be achieved by active follow up with behavioral therapy, nutrition education and exercise [108]. Unsupervised VLCD can results in serious complications including death of patient [108]. Evidence showed that VLCD for longer duration can even lead to cardiac complication and hence death. No death rate was observed when VLCD has been taken for 8 weeks or less [112].

\section{Weight reduction maintenance with VLCD}

VLCD is known to be superior treatment as compared to LCD to achieve short term weight loss but achieving long term weight loss maintenance is difficult. The National Heart, Lung, and Blood Institute (NHLBI) expert panel recommended LCD (1000 to $1500 \mathrm{kcal} /$ day) over VLCD. The panel's decision was based on data from randomized trials that reported no differences in long-term weight losses between VL$\mathrm{CDs}$ and LCDs; in fact, greater weight regain was observed after VLCD treatment [113]. However, despite this expert panel's conclusion, the majority of individual randomized trials reported greater long-term weight losses after VLCDs. For instance, in a meta-analysis of long-term studies, demonstrated that VLCD treatment has been association in achieving greater long-term weight loss as compared to LCD [114]. Similar- ly, Astrup and Rossner illustrated that the larger initial weight loss induced by VLCD is related to greater long-term weight reduction [115], Although, long term weight loss with VLCD can be obtained when combined with behavioral therapy and regular exercise. Considerably, exercise will not increase the weight reduction, but it is helpful in maintaining weight loss [116]. Behavioral therapy (food diaries, shopping strategies, dietary preference) and exercise can help to maintain weight loss for 1- 3 years after VLCD. However, VLDL diets results in increasing psychological stress and hormone level such as cortisol that can eventually induce negative effects on insulin resistance and lower dietary success [117]. Therefore, psychological counselling is very important for patients receiving VLCD. Consequently, total duration VLCD intervention consist of 4-6 months that includes introduction of VLCD for 8 weeks, refeeding and stability phase, is helpful to reduce weight without any further complications. After VLCD treatment (4-6 months), patients should gradually introduce to LCD along with behavioral modification and exercise to sustain body weight.

\section{CONCLUSION}

The number of cases of T2D is increasing rapidly worldwide and contributes to enormous social and personal suffering and economic burden. Patients present with hyperglycemia due to the progressive deterioration of glucose metabolism over the years. High-calorie diets and physical inactivity are major contributors to the causes and initiation of T2D. There is a strong evidence that physical activity and dietary modalities reduce the risk of morbidity and mortality in individuals with T2D. Strategies that deal with this global problem of increased rates of T2D and its complications should focus on physical activity and how to reverse the condition at the population level. Moreover, calorie restriction diets also prove to be beneficial in the management of T2D. Therefore, future research is required to include long-term lifestyle interventions including very low-calorie diets and exercise and to analyzed the remission outcomes of patients with T2D. 


\section{Acknowledgements}

Authors would like to acknowledge the Department of Nutrition and Health as well as the College of Medicine and Health Sciences, United Arab Emirates University for their ongoing support. JF would like to acknowledge the Australian Government for their support through RTP training scholarships. JF was also supported by a University of Melbourne PhD Stipend. JF and VA would like to thank the Institute for Health and Sport, Victoria University Australia for their support.

\section{Disclosure of interest} interest.

The authors do not have any conflict of

\section{REFERENCES}

1. Siddiqui A, Siddiqui SA, Siddiqui AA, Siddiqui SA, Ahmad S, Siddiqui S, et al. Diabetes:Mechanism, Pathophysiology and Management-A Review. Int J Drug Dev Res 2013; 5: 1-23.

2. Ahmed AM. History of diabetes mellitus. Saudi Med J 2002; 23: 373-8.

3. International diabetes federation. IDF Diabetes Atlas. 2017.

4. American Diabetes Association AD. 2. Classification and Diagnosis of Diabetes. Diabetes Care 2017; 40: S11-24. https://doi.org/10.2337/ dc17-S005.

5. Wei M, Brandhorst S, Shelehchi M, Mirzaei H, Cheng CW, Budniak J, et al. Fasting-mimicking diet and markers/risk factors for aging, diabetes, cancer, and cardiovascular disease. Sci Transl Med 2017; 9. https://doi.org/10.1126/scitranslmed.aai8700.

6. Carter S, Clifton PM, Keogh JB. Intermittent energy restriction in type 2 diabetes: A short discussion of medication management. World J Diabetes 2016; 7: 627. https://doi.org/10.4239/wjd. v7.i20.627.

7. Jackness C, Karmally W, Febres G, Conwell IM, Ahmed L, Bessler M, et al. Very lowcalorie diet mimics the early beneficial effect of rouxen-Y gastric bypass on insulin sensitivity and $\beta$-cell function in type 2 diabetic patients. Diabetes 2013; 62: 3027-32. https://doi.org/10.2337/ $\mathrm{db} 12-1762$.

8. Wing RR, Lang W, Wadden TA, Safford M, Knowler WC, Bertoni AG, et al. Benefits of modest weight loss in improving cardiovascular risk factors in overweight and obese individuals with type 2 diabetes. Diabetes Care 2011; 34: 1481-6. https://doi.org/10.2337/dc10-2415.

9. Cersosimo E, Triplitt C, Solis H, Mandarino L, DeFronzo R. Pathogenesis of type 2 diabetes mellitus. 2018.

10. Zaccardi F, Webb DR, Yates T, Davies MJ. Pathophysiology of type 1 and type 2 diabetes mellitus: A 90-year perspective. Postgrad Med J 2016; 92: 63-9. https://doi.org/10.1136/postgradmedj-2015-133281.

11. Groop LC, Bonadonna RC, Delprato S, Ratheiser K, Zyck K, Ferrannini E, et al. Glucose and Free Fatty Acid Metabolism in Non-insulin-dependent Diabetes Mellitus Evidence for Multiple Sites of Insulin Resistance. J Clin Invest 1989; 84: 205-13.

12. Bergman RN. Non-esterified fatty acids and the liver: Why is insulin secreted into the portal vein? Diabetologia 2000; 43: 946-52. https://doi. org/10.1007/s001250051474.

13. Ward W, Beard J, Porte Jr D. Clinical aspects of islet B-cell function in non-insulin-dependent diabetes mellitus. Diabetes / Metab Rev 1986; 2: 297-313.

14. Weir GC, Bonner-Weir S. Five of stages of evolving $\beta$-cell dysfunction during progression to diabetes. Diabetes, vol. 53, 2004. https://doi. org/10.2337/diabetes.53.suppl_3.S16.

15. Mahler RJ, Adler ML. Type 2 Diabetes Mellitus: Update on Diagnosis, Pathophysiology, and Treatment. J Clin Endocrinol Metab 1999; 84: 1165-71. https://doi.org/10.1210/ jcem.84.4.5612.

16. Baynest HW. Classification, Pathophysiology, Diagnosis and Management of Diabetes Mellitus. J Diabetes Metab 2015; 06: 1-9. https://doi. org/10.4172/2155-6156.1000541.

17. Bril F, Cusi K. Basic Concepts in Insulin Resistance and Diabetes Treatment. Dermatology and Diabetes, Springer International Publishing; 2018, p. 19-35. https://doi.org/10.1007/978-3319-72475-1 3.

18. Lu Y, Li M, Rongxiang Wang A. View Insulin Resistance from an Interaction Between Pancreatic Islets and Peripheral Tissues. Clin Med Res 2018; 7: 124-30. https://doi.org/10.11648/j. cmr.20180705.14.

19. Carey D, Jenkins A, Campbell L, Freund J, Chisholm D. Abdominal fat and insulin resistance in normal and overweight women: direct measurements reveal a strong relationship in subjects at both low and high risk of NIDDM. Diabetes 1996; 45: 633-8.

20. Kranendonk MEG, van Herwaarden JA, Stupkova T, Jager W de, Vink A, Moll FL, et al. Inflammatory characteristics of distinct abdominal adipose tissue depots relate differently to metabolic risk factors for cardiovascular disease: Distinct 
fat depots and vascular risk factors. Atherosclerosis 2015; 239: 419-27. https://doi.org/10.1016/j. atherosclerosis.2015.01.035.

21. Ferroni P, Basili S, Falco A, Davì G. Inflammation, insulin resistance, and obesity. Curr Atheroscler Rep 2004; 6: 424-31. https://doi. org/10.1007/s11883-004-0082-x.

22. Asmat U, Abad K, Ismail K. Diabetes mellitus and oxidative stress-A concise review. Saudi Pharm J 2016; 24: 547-53. https://doi. org/10.1016/J.JSPS.2015.03.013.

23. Stolar M. Glycemic Control and Complications in Type 2 Diabetes Mellitus. Am J Med 2010; 123: S3-11. https://doi.org/10.1016/j.amjmed.2009.12.004.

24. Pickup JC, Crook MA. Is Type II diabetes mellitus a disease of the innate immune system? Diabetologia 1998; 41: 1241-8. https://doi. org/10.1007/s001250051058.

25. Bosevski M, Stojanovska L, Apostolopoulos V. Inflammatory biomarkers: impact for diabetes and diabetic vascular disease. Acta Biochim Biophys Sin (Shanghai) 2015; 47: 1029-31.

26. Pickup J. Inflammation and activated innate immunity in the pathogenesis of type 2 diabetes. Diabetes Care 2004; 27: 813-23. https://doi. org/10.2337/DIACARE.27.3.813.

27. Müller S, Martin S, Koenig W, Hanifi-Moghaddam P, Rathmann W, Haastert B, et al. Impaired glucose tolerance is associated with increased serum concentrations of interleukin 6 and co-regulated acute-phase proteins but not TNF- $\alpha$ or its receptors. Diabetologia 2002; 45: 805-12. https://doi.org/10.1007/s00125-002-0829-2.

28. Ogata A, Morishima A, Hirano T, Hishitani Y, Hagihara K, Shima Y, et al. Improvement of $\mathrm{HbA} 1 \mathrm{c}$ during treatment with humanised anti-interleukin 6 receptor antibody, tocilizumab. Ann Rheum Dis 2011; 70: 1164-5. https://doi. org/10.1136/ard.2010.132845.

29. Jung SH, Park HS, Kim K-S, Choi WH, Ahn CW, Kim BT, et al. Effect of weight loss on some serum cytokines in human obesity: increase in IL-10 after weight loss. J Nutr Biochem 2008; 19: 371-5. https://doi.org/10.1016/J.JNUTBIO.2007.05.007.

30. Li ZZ, Liu JB, Li L, Jiao L, Chen L. Intensive therapy for diabetes through influence on innate immune system. Med Hypotheses 2009; 72: 6756. https://doi.org/10.1016/j.mehy.2009.01.028.

31. Bray G, Frühbeck G, Ryan D, Wilding J. Management of obesity. Lancet 2016; 387: 1947-56. https://doi.org/10.1016/S0140-6736(16)00271-3.

32. Haslam D. Obesity: a medical history. Obes Rev 2007; 8: 31-6. https://doi.org/10.1111/j.1467789X.2007.00314.x.

33. Haslam D, James W. OBESITY. Lancet 2006; 366: 1197-209.
34. Apostolopoulos V, de Courten M, Stojanovska L, Blatch G, Tangalakis K, de Courten B. The complex immunological and inflammatory network of adipose tissue in obesity. Mol Nutr Food Res 2016; 60: 43-57. https://doi.org/10.1002/ mnfr.201500272.

35. Vozarova B, Metz C, Stefan N, Hanson R, Lindsay R, Bucala, R., ... \& Tataranni P. Plasma concentrations of macrophage migration inhibitory factor are elevated in Pima Indians compared to Caucasians and are associated with insulin resistance. Diabetologia 2002; 45: 1739-41. https:// doi.org/10.1007/s00125-002-0896-4.

36. Sam S, Mazzone T. Adipose tissue changes in obesity and the impact on metabolic function. Transl Res 2014; 164: 284-92.

37. Bray G. Medical consequences of obesity. J Clin Endocrinol Metab 2004; 89: 2583-9.

38. Imamura F, Micha R, Khatibzadeh S, Fahimi S, Shi P, Powles, J. ... \& Global Burden of Diseases Nutrition and Chronic Diseases Expert Group (NutriCoDE. (2015). Dietary quality among men and women in 187 countries in 1990 and 2010: a systematic assessment. Lancet Glob Heal 2015; 3: $132-42$.

39. Mozaffarian D. Dietary and Policy Priorities for Cardiovascular Disease, Diabetes, and Obesity. Circulation 2016;133:187-225. https://doi. org/10.1161/CIRCULATIONAHA.115.018585.

40. Sami W, Ansari T, Butt NS, Hamid MRA. Effect of diet on type 2 diabetes mellitus: A review. Int J Heal Sci 2017; 11: 65.

41. Becker GF, Passos EP, Moulin CC. Short-term effects of a hypocaloric diet with low glycemic index and low glycemic load on body adiposity, metabolic variables, ghrelin, leptin, and pregnancy rate in overweight and obese infertile women: A randomized controlled trial. Am J Clin Nutr 2015; 102: 1365-72. https://doi.org/10.3945/ ajcn.115.117200.

42. Miller CT, Fraser SF, Selig SE, Rice T, Grima M, Straznicky NE, et al. The functional and clinical outcomes of exercise training following a very low energy diet for severely obese women: Study protocol for a randomised controlled trial. Trials 2016; 17: 1-12. https://doi.org/10.1186/s13063016-1232-5.

43. Armenise C, Lefebvre G, Carayol J, Bonnel S, Bolton J, Di Cara A, et al. Transcriptome profiling from adipose tissue during a low-calorie diet reveals predictors of weight and glycemic outcomes in obese, nondiabetic subjects. Am J Clin Nutr 2017; 106: 736-46. https://doi.org/10.3945/ ajcn.117.156216.

44. Nabulsi A, Folsom A, Heiss G, Nabulsi A, Folsom A, Heiss G, et al. Fasting hyperinsulinemia and cardiovascular disease risk factors in nondi- 
abetic adults: stronger associations in lean versus obese subjects. Metabolism 1995; 44: 914-22.

45. Larson-Meyer D, Heilbronn L, Redman L, Newcomer B, Frisard M, Anton S, et al. Effect of calorie restriction with or without exercise on insulin sensitivity, $\beta$-cell function, fat cell size, and ectopic lipid in overweight subjects. Diabetes Care 2006; 29: 1337-44.

46. Kelley DE, Wing R, Buonocore C, Sturis J, Polonsky K, Fitzsimmons M. Relative effects of calorie restriction and weight loss in noninsulin-dependent diabetes mellitus. J Clin Endocrinol Metab 1993; 77: 1287-93. https://doi. org/10.1210/jcem.77.5.8077323.

47. Riecke B, Christensen R, Christensen P, Leeds A, Boesen M, Lohmander L, et al. Comparing two low-energy diets for the treatment of knee osteoarthritis symptoms in obese patients: a pragmatic randomized clinical trial. Osteoarthr Cartil 2010; 18: 746-54.

48. Rehackova L, Araújo-Soares V, Steven S, Adamson AJ, Taylor R, Sniehotta FF. Behaviour change during dietary Type 2 diabetes remission: a longitudinal qualitative evaluation of an intervention using a very low energy diet. Diabet Med 2020; 37: 953-62. https://doi.org/10.1111/ dme.14066.

49. Bistrian B, Blackburn G, Flatt J, Sizer J, Scrimshaw N, Sherman M. Nitrogen metabolism and insulin requirements in obese diabetic adults on a protein-sparing modified fast. Diabetes 1976; 25: 494-504.

50. Brown A, Taheri S. Very-low-energy diets for weight loss in patients with kidney disease. J Kidney Care 2018; 3: 14-22. https://doi. org/10.12968/jokc.2018.3.1.14.

51. Tamayo T, Rosenbauer J, Spijkerman A, Baan C, Forouhi $\mathrm{N}, \ldots$ \& Rathmann W. Diabetes in Europe: an update. Diabetes Res Clin Pract 2014; 103: 206-17.

52. Waxman A. WHO's global strategy on diet, physical activity and health: Response to a worldwide epidemic of non-communicable diseases. Scand J Nutr 2004; 48: 58-60. https://doi. org/10.1080/11026480410033539.

53. Apostolopoulos V, Borkoles E, Polman R, Stojanovska L. Physical and immunological aspects of exercise in chronic diseases. Immunotherapy $2014 ; 6$ : 1145-57. https://doi.org/10.2217/ imt.14.76.

54. Sigal RJ, Kenny GP, Boulé NG, Wells GA, Prud'homme D, Fortier M, et al. Effects of Aerobic Training, Resistance Training, or Both on Glycemic Control in Type 2 Diabetes. Ann Intern Med 2007; 147: 357. https://doi.org/10.7326/00034819-147-6-200709180-00005.

55. Boulé NG, Haddad E, Kenny GP, Wells GA, Sigal RJ. Effects of exercise on glycemic con- trol and body mass in type 2 diabetes mellitus: A meta-analysis of controlled clinical trials. J Am Med Assoc 2001;286:1218-27. https://doi. org/10.1001/jama.286.10.1218.

56. Nelson M, Rejeski W, Blair S, Duncan P, Judge J, King A, et al. Physical Activity and Public Health in Older Adults: Recommendation From the American College of Sports Medicine and the American Heart Association. Circulation 2007;116:1094-105.

57. Colberg SR, Castorino K, Jovanovič L. Prescribing physical activity to prevent and manage gestational diabetes. World J Diabetes 2013;4:25662. https://doi.org/10.4239/wjd.v4.i6.256.

58. Pourranjbar M, Arabnejad N, Naderipour K, Rafie F. Effects of Aerobic Exercises on Serum Levels of Myonectin and Insulin Resistance in Obese and Overweight Women. J Med Life 2018; 11: 381-6. https://doi.org/10.25122/jml-2018-0033.

59. Wallberg-Henriksson H, Rincon J, Zierath JR. Exercise in the Management of Non???Insulin-Dependent Diabetes Mellitus. Sport Med 1998; 25: 25-35. https://doi.org/10.2165/00007256199825010-00003.

60. Sigal RJ, Kenny GP, Wasserman DH, Castaneda-Sceppa C. Physical activity/exercise and type 2 diabetes. Diabetes Care 2004; 27: 2518-39. https://doi.org/10.2337/diacare.27.10.2518.

61. Röhling M, Herder C, Roden M, Stemper T, Müssig K. Effects of Long-Term Exercise Interventions on Glycaemic Control in Type 1 and Type 2 Diabetes: a Systematic Review. Exp Clin Endocrinol Diabetes 2016; 124: 487-94. https:// doi.org/10.1055/s-0042-106293.

62. Yang Z, Scott C, Mao C, Tang J, Farmer A. Resistance exercise versus aerobic exercise for type 2 diabetes: a systematic review and meta-analysis. Sport Med 2014; 44: 287-499.

63. Pudkasam S, Tangalakis K, Chinlumprasert N, Apostolopoulos V, Stojanovska L. Breast cancer and exercise: the role of adiposity and immune markers. Maturitas 2017; 105: 16-22.

64. Stojanovska L, Apostolopoulos V, Polman R, Borkoles E. To exercise, or, not to exercise, during menopause and beyond. Maturitas 2014; 77: 318-23.

65. Church T, Blair S, Cocreham S, Johannsen N, Johnson W, Kramer K, et al. Effects of aerobic and resistance training on hemoglobin A1c levels in patients with type 2 diabetes: a randomized controlled trial. Jama 2010; 304: 2253-62.

66. Kadoglou NPE, Fotiadis G, Kapelouzou A, Kostakis A, Liapis CD, Vrabas IS. The differential anti-inflammatory effects of exercise modalities and their association with early carotid atherosclerosis progression in patients with Type 2 diabetes. Diabet Med 2013;30:e41-50. https:// doi.org/10.1111/dme.12055. 
67. Kyu HH, Bachman VF, Alexander LT, Mumford JE, Afshin A, Estep K, et al. Physical activity and risk of breast cancer, colon cancer, diabetes, ischemic heart disease, and ischemic stroke events: systematic review and dose-response meta-analysis for the Global Burden of Disease Study 2013. BMJ 2016; 354: i3857. https://doi. org/10.1136/bmj.i3857.

68. Ried-Larsen M, Johansen MY, MacDonald CS, Hansen KB, Christensen R, Wedell-Neergaard $\mathrm{A}$, et al. Type 2 diabetes remission 1 year after an intensive lifestyle intervention: A secondary analysis of a randomized clinical trial. Diabetes, Obes Metab 2019; 21: 2257-66. https://doi. org/10.1111/dom.13802.

69. Johansen MY, Macdonald CS, Hansen KB, Karstoft K, Christensen R, Pedersen M, et al. Effect of an intensive lifestyle intervention on glycemic control in patients with type 2 diabetes: A randomized clinical trial. JAMA - J Am Med Assoc 2017; 318: 637-46. https://doi.org/10.1001/ jama.2017.10169.

70. Schrauwen P. High-fat diet, muscular lipotoxicity and insulin resistance. Poceedings Nutr Soc 2007; 66: 33-41.

71. Johnson M, Robinson M, Nair N. Skeletal muscle aging and the mitochondrion. Trends Endocrinol Metab 2013; 24: 247-56.

72. Amati F, Dubé J, Coen P, Stefanovic-Racic M, Toledo F, Goodpaster B. Physical inactivity and obesity underlie the insulin resistance of aging. Am Diabetes Assoc 2009; 32: 1547-9.

73. Megeney LA, Neufer PD, Dohm GL, Tan MH, Blewett CA, Elder GC, et al. Effects of muscle activity and fiber composition on glucose transport and GLUT-4. Am J Physiol Metab 1993; 264: E583-93. https://doi.org/10.1152/ajpendo.1993.264.4.E583.

74. Menshikova E V, Ritov VB, Dube JJ, Amati F, Stefanovic-Racic M, Toledo FGS, et al. Calorie Restriction-induced Weight Loss and Exercise Have Differential Effects on Skeletal Muscle Mitochondria Despite Similar Effects on Insulin Sensitivity. Journals Gerontol Ser A 2018;73:817. https://doi.org/10.1093/gerona/glw328.

75. Caro JF, Sinha MK, Raju SM, Ittoop O, Pories WJ, Flickinger EG, et al. Insulin receptor kinase in human skeletal muscle from obese subjects with and without noninsulin dependent diabetes. J Clin Invest 1987; 79: 1330-7. https://doi. org/10.1172/JCI112958.

76. Aguiar EJ, Morgan PJ, Collins CE, Plotnikoff RC, Callister R. Efficacy of interventions that include diet, aerobic and resistance training components for type 2 diabetes prevention: a systematic review with meta-analysis. Int J Behav Nutr Phys Act 2014;11:2. https://doi.org/10.1186/14795868-11-2.
77. Snel M, van Diepen JA, Stijnen T, Pijl H, Romijn JA, Meinders AE, et al. Immediate and long-term effects of addition of exercise to a 16-week very low calorie diet on low-grade inflammation in obese, insulin-dependent type 2 diabetic patients. Food Chem Toxicol 2011;49:3104-11. https:// doi.org/10.1016/j.fct.2011.09.032.

78. Taheri S, Chagoury O, Zaghloul H, Elhadad S, Ahmed SH, Omar O, et al. Diabetes Intervention Accentuating Diet and Enhancing Metabolism (DIADEM-I): a randomised controlled trial to examine the impact of an intensive lifestyle intervention consisting of a low-energy diet and physical activity on body weight and metabolism in early type 2 diabetes mellitus: study protocol for a randomized controlled trial. Trials 2018; 19 : 284. https://doi.org/10.1186/s13063-018-2660-1.

79. Lean ME, Leslie WS, Barnes AC, Brosnahan N, Thom G, McCombie L, et al. Primary careled weight management for remission of type 2 diabetes (DiRECT): an open-label, cluster-randomised trial. Lancet 2018;391:541-51. https:// doi.org/10.1016/S0140-6736(17)33102-1.

80. Weiss EP, Albert SG, Reeds DN, Kress KS, McDaniel JL, Klein S, et al. Effects of matched weight loss from calorie restriction, exercise, or both on cardiovascular disease risk factors: A randomized intervention trial. Am J Clin Nutr 2016; 104: 576-86. https://doi.org/10.3945/ ajcn.116.131391.

81. Salas-Salvadó J, Díaz-López A, Ruiz-Canela M, Basora J, Fitó M, Corella D, et al. Effect of a lifestyle intervention program with energy-restricted Mediterranean diet and exercise on weight loss and cardiovascular risk factors: One-year results of the PREDIMED-Plus trial. Diabetes Care 2019;42:777-88. https://doi.org/10.2337/dc180836.

82. Steven S, Hollingsworth KG, Al-Mrabeh A, Avery L, Aribisala B, Caslake M, et al. Very Low-Calorie Diet and 6 Months of Weight Stability in Type 2 Diabetes: Pathophysiological Changes in Responders and Nonresponders. Diabetes Care 2016; 39: 808-15. https://doi. org/10.2337/dc15-1942.

83. Oberhauser F, Schulte D, Faust M, Güdelhöfer H, Hahn M, Müller N, et al. Weight Loss Due to a Very Low Calorie Diet Differentially Affects Insulin Sensitivity and Interleukin-6 Serum Levels in Nondiabetic Obese Human Subjects. Horm Metab Res 2012; 44: 465-70. https://doi. org/10.1055/s-0032-1306341.

84. Pedersen LR, Olsen RH, Anholm C, Astrup A, Eugen-Olsen J, Fenger M, et al. Effects of 1 year of exercise training versus combined exercise training and weight loss on body composition, low-grade inflammation and lipids in overweight patients with coronary artery disease: A random- 
ized trial. Cardiovasc Diabetol 2019;18. https:// doi.org/10.1186/s12933-019-0934-x.

85. Wing RR, Bolin P, Brancati FL, Bray GA, Clark JM, Coday M, et al. Cardiovascular Effects of Intensive Lifestyle Intervention in Type 2 Diabetes. N Engl J Med 2013; 369: 145-54. https://doi. org/10.1056/NEJMoa1212914.

86. Astbury N, Aveyard P, Nickless A, Hood K, Corfield K, Lowe R, et al. Doctor Referral of Overweight People to Low Energy total diet replacement Treatment (DROPLET): pragmatic randomised controlled trial. BMJ 2018; 362: 3760.

87. Umphonsathien M, Prutanopajai P, Aiam-O-Ran $\mathrm{J}$, Thararoop T, Karin A, Kanjanapha C, et al. Immediate and long-term effects of a very-lowcalorie diet on diabetes remission and glycemic control in obese Thai patients with type 2 diabetes mellitus. Food Sci Nutr 2019; 7: 1113-22. https://doi.org/10.1002/fsn3.956.

88. Valsesia A, Saris WHM, Astrup A, Hager J, Masoodi M. Distinct lipid profiles predict improved glycemic control in obese, nondiabetic patients after a low-caloric diet intervention: The Diet, Obesity and Genes randomized trial. Am J Clin Nutr 2016; 104: 566-75. https://doi. org/10.3945/ajen.116.137646.

89. Meyer A, Montastier E, Hager J, Saris WHM, Astrup A, Viguerie N, et al. Plasma metabolites and lipids predict insulin sensitivity improvement in obese, nondiabetic individuals after a 2-phase dietary intervention. Am J Clin Nutr 2018; 108: 13-23. https://doi.org/10.1093/ajcn/nqy087.

90. Christensen P, Meinert Larsen T, WesterterpPlantenga M, Macdonald I, MartinezJA, Handjiev $\mathrm{S}$, et al. Men and women respond differently to rapid weight loss: Metabolic outcomes of a multi-centre intervention study after a lowenergy diet in 2500 overweight, individuals with pre-diabetes (PREVIEW). Diabetes, Obes Metab 2018; 20: 2840-51. https://doi.org/10.1111/ dom. 13466.

91. Carter S, Clifton P, Keogh J. The effects of intermittent compared to continuous energy restriction on glycaemic control in type 2 diabetes; a pragmatic pilot trial. Diabetes Res Clin Pract 2016;122:106-12. https://doi.org/10.1016/J. DIABRES.2016.10.010.

92. Williams K V, Mullen ML, Kelley DE, Wing RR. The effect of short periods of caloric restriction on weight loss and glycemic control in type 2 diabetes. Diabetes Care 1998;21:2-8. https://doi. org/10.2337/diacare.21.1.2.

93. Oh M, Kim S, An K-Y, Min J, Yang HI, Lee J, et al. Effects of alternate day calorie restriction and exercise on cardio-metabolic risk factors in overweight and obese adults: an exploratory randomized controlled study. BMC Public
Health 2018;18:1124. https://doi.org/10.1186/ s12889-018-6009-1.

94. Atkinson, R.L.; Dietz, W.H.; Foreyt, J.P.; Goodwin, N.J.; Hill, J.O.; Hirsch, J.; Pi-Sunyer, F.X.; Weinsier, R.L.; Wing, R.; Yanovski, S.Z. Very low-calorie diets. JAMA 1993, 270, 967-974.

95. Murray, D.C. Treatment of overweight: I. Relationship between initial weight and weight change during behavior therapy of overweight individuals: analysis of data from previous studies. Psychological Reports 1975, 37, 243-248.

96. Tsai, A.G.; Wadden, T.A. The evolution of verylow-calorie diets: an update and meta-analysis. Obesity 2006, 14, 1283-1293.

97. Liddle, R.A.; Goldstein, R.B.; Saxton, J. Gallstone formation during weight-reduction dieting. Archives of internal medicine 1989, 149, 1750-1753.

98. Weinsier, R.L.; Wilson, L.J.; Lee, J. Medically safe rate of weight loss for the treatment of obesity: a guideline based on risk of gallstone formation. Elsevier: 1995.

99. Lim, E.L.; Hollingsworth, K.G.; Aribisala, B.S.; Chen, M.J.; Mathers, J.C.; Taylor, R. Reversal of type 2 diabetes: normalisation of beta cell function in association with decreased pancreas and liver triacylglycerol. Diabetologia 2011, 54, 2506-2514.

100. Bray, G.A.; Gray, D.S. Obesity. Part I-Pathogenesis. Western Journal of Medicine 1988, 149, 429.

101. National Institutes of, H. Clinical guidelines for the identification, evaluation, and treatment of overweight and obesity in adults-the evidence report. Obes Res 1998, 6, 51S-209S.

102. Fock, K.M.; Khoo, J. Diet and exercise in management of obesity and overweight. Journal of gastroenterology and hepatology 2013, 28, 59-63.

103. Merritt, R.J.; Bistrian, B.R.; Blackburn, G.L.; Suskind, R.M. Consequences of modified fasting in obese pediatric and adolescent patients. I. Protein-sparing modified fast. The Journal of pediatrics 1980, 96, 13-19.

104. Pencharz, P.B.; Motil, K.J.; Parsons, H.G.; Duffy, B.J. The effect of an energy-restricted diet on the protein metabolism of obese adolescents: nitrogen-balance and whole-body nitrogen turnover. Clinical Science 1980, 59, $13-18$.

105. Thompson, J.S.; Robbins, J.; Cooper, J.K. Nutrition and immune function in the geriatric population. Clinics in geriatric medicine $\mathbf{1 9 8 7}$, 3, 309-317.

106. Metzger, B.E.; Freinkel, N. Accelerated starvation in pregnancy: implications for dietary treatment of obesity and gestational diabetes mellitus. Neonatology 1987, 51, 78-85. 
107. Ness-Abramof, R.; Apovian, C.M. Diet modification for treatment and prevention of obesity. Endocrine 2006, 29, 5-9.

108. Wadden, T.A.; Stunkard, A.J.; Brownell, K.D. Very low calorie diets: their efficacy, safety, and future. Annals of Internal Medicine 1983, 99, 675-684.

109. Genuth, S. Supplemented fasting in the treatment of obesity and diabetes. American Journal of Clinical Nutrition (USA) 1979.

110. Amatruda, J.M.; Richeson, J.F.; Welle, S.L.; Brodows, R.G.; Lockwood, D.H. The safety and efficacy of a controlled low-energy ('very-lowcalorie') diet in the treatment of non-insulindependent diabetes and obesity. Archives of Internal Medicine 1988, 148, 873-877.

111. Henry, R.R.; Scheaffer, L.; Olefsky, J.M. Glycemic effects of intensive caloric restriction and isocaloric refeeding in noninsulindependent diabetes mellitus. The Journal of Clinical Endocrinology \& Metabolism 1985, 61, 917-925.

112. Sours, H.E.; Frattali, V.P.; Brand, C.D.; Feldman, R.A.; Forbes, A.L.; Swanson, R.C.; Paris, A.L. Sudden death associated with very low calorie weight reduction regimens. The
American journal of clinical nutrition 1981, 34, 453-461.

113. National, H.; Lung; Blood, I.; National Institute of, D.; Digestive; Kidney, D. Clinical guidelines on the identification, evaluation, and treatment of overweight and obesity in adults: the evidence report; National Heart, Lung, and Blood Institute: 1998.

114. Anderson, J.W.; Konz, E.C.; Frederich, R.C.; Wood, C.L. Long-term weight-loss maintenance: a meta-analysis of US studies. The American journal of clinical nutrition 2001, 74, 579-584.

115. Astrup, A.; Rössner, S. Lessons from obesity management programmes: greater initial weight loss improves long-term maintenance. obesity reviews 2000, 1, 17-19.

116. Pavlou, K.N.; Krey, S.; Steffee, W.P. Exercise as an adjunct to weight loss and maintenance in moderately obese subjects. The American Journal of Clinical Nutrition 1989, 49, 11151123.

117. Tomiyama, A.J.; Mann, T.; Vinas, D.; Hunger, J.M.; DeJager, J.; Taylor, S.E. Low calorie dieting increases cortisol. Psychosomatic medicine 2010, 72, 357. 


\title{
Резиме
}

ЕФЕКТОТ НА ОГРАНИЧУВАЊЕТО НА КАЛОРИИТЕ И ВЕЖБАЊЕТО ВРЗ ДИЈАБЕТЕС ТИП 2

\author{
Хира Шакор${ }^{1}$, Васо Апостолопулос' \\ Лајла Чеик Исмаил ${ }^{4,5}$, Ајша Салем Обаид С. ал Дахери ${ }^{1}$, Лили Стојановска ${ }^{1,2}$
}

\author{
${ }^{1}$ Оддел за исхрана и здравје, Колеџ за медицина и здравствени науки, Обединети Арапски \\ Емирати, Ал Аин, Обединети Арапски Емирати \\ ${ }^{2}$ Институт за здравје и спорт, Универзитет Викторија, Мелбурн, Австралија \\ ${ }^{3}$ Оддел за западна медицина, Медицинска школа во Мелбурн, Универзитет во Мелбурн, Сент \\ Албанс, Австралија \\ ${ }^{4}$ Оддел за клиничка исхрана и диететика, Колеџ за здравствени науки, Универзитет во Шарџа, \\ Шарџа, Обединети Арапски Емирати \\ ${ }^{5}$ Оддел Nuffield за здравјето на жените и репродуктивното здравје, Универзитет во Оксфорд, \\ Оксфорд, Велика Британија
}

Дијабетес тип 2 (T2D) е хронична состојба, општо се смета за неповратна и е меѓу првите 10 причини за смрт на глобално ниво. Карактеристика на T2D е хипергликемијата, што произлегува од нарушувања на чувствителноста на инсулин, секрецијата на инсулин, дисфункцијата на $\beta$-клетките и инсулинска резистенција. Неколку клинички фактори и фактори на живот се вклучени во прогресијата на T2D, како што се дебелината и физичката неактивност. Висококалоричната диета најмногу придонесува за развојот на дебелината, што резултира со T2D, бидејќи дебелината или зголеменото интраабдоминално масно ткиво е поврзано со инсулинската резистенција. Технолошкиот напредок придонесе поединци да имаат повеќе седентарен начин на живот, што доведува до дебелина и T2D. T2D може да се третира со интервенции во животниот стил, како што се диета и вежбање. Овде го потенцираме позитивното влијание на многу нискокалоричната диета (VLCD) и модалитетите на животниот стил во третманот и превенцијата на T2D. Вклучување на VLCD 400-800 kcal/ден за време од 8 недели и $\geq 150$ минути вежбање петпати неделно - бидејќи интервенциите во животниот стил може да ги намалат нивоата на глукоза до нормала, да го намалат $\mathrm{HbA1c}$ и да ја подобрат инсулинската резистенција и чувствителност. Затоа, потенцијалниот механизам за одржување на хомеостазата на глукозата и ремисијата на T2D co VLCD и вежбање ја намалува телесната тежина.

Клучни зборови: хипергликемија, нискокалорична диета, чувствителност на инсулин, инсулинска резистенција, дијабетес тип 2 